\title{
UNDERDEVELOPMENT OF RURAL TOURISM IN SERBIA: CAUSES, CONSEQUENCES AND POSSIBLE DIRECTIONS OF DEVELOPMENT
}

\author{
Gordana Radovic ${ }^{1}$
}

*Corresponding author E-mail: gordana.radovic09@gmail.com

\author{
A R T I C L E I N F O \\ Review Article \\ Received: 15 May 2020 \\ Accepted: 27 October 2020 \\ doi:10.5937/ekoPolj2004337R \\ UDC 502.131.1:338.48-44 \\ $(1-22)(497.11)$
}

\section{Keywords:}

rural tourism, balanced rural development, financing, association, Serbia

JEL: R59

\begin{abstract}
A B S T R A C T
The aim of this paper is to analyze the development of rural tourism in Serbia. The paper uses the method of survey research, analysis, synthesis, comparative and statistical methods. The author concludes that rural tourism in Serbia is underdeveloped. The reasons for this are numerous, and they primarily relate to problems and limitations in the development of supply, but also to the lack of demand. The consequences are the economic and social decline of rural areas. In order to develop rural tourism in Serbia, it is necessary to adopt new strategic documents, regulations and provide favorable continuous sources of financing for the development of all segments of the offer. For the purpose of balanced rural development, it is necessary to form an association at the national level, which should have branches in all administrative districts and play a key role in the further development of rural tourism in Serbia.
\end{abstract}

(C) 2020 EA. All rights reserved.

\section{Introduction}

Tourism as a phenomenon, by its spatial, economic, sociological, psychological, cultural, political and other connotations, has no counterpart in any otherphenomenon of the modern world (Lakićević \& Žarevac, 2014). Tourism has become increasingly important industry, and there are different approaches to defining and measuring the performance of a tourist destination (Durkalić et al., 2019). Rural tourism can be called a "model of rural development". This model implies the development of nonagricultural activities, but also the development of agriculture as a primary activity in rural areas. Also, this model should make it possible to stop the departure of the working population from rural to urban areas.

Factors influencing the development of rural tourism can be divided into factors influencing the increase of supply and factors influencing the growth of demand. Rural tourism in Europe has recorded a rapid growth in the second half of the twentieth century.

1 Gordana Radović, Ph.D, Scientific associate, Director, „Dnevnik-Poljoprivrednik“ AD Novi Sad, Serbia, Phone: +381 641378 643, E-mail: gordana.radovic09@gmail.com, ORCID ID (https://orcid.org/0000-0001-9770-6306) 
"The growth rate of tourist demand in rural areas on this continent has increased, in the period from $1980-2000$ by $52 \%$, which is by far the largest growth compared to other tourist regions" (Bošković, 2003, p.65). Affirmation of the development of rural tourism in Serbia has a base if we look at the availability of natural and social resources, the importance of agriculture, the possibility of rural development based on a multisector approach. Also, there is a need to slow down migration from rural to urban areas for the survival of Serbian villages. However, the average capacity occupancy in rural tourism in Serbia is only 4\% (Program for the development of sustainable rural tourism in the Republic of Serbia, 2011), and the average capacity occupancy in rural tourism in the European Union is 25\% (Bartlet, 2006).

The European Union strongly supports sustainable development, allocating around $40 \%$ of the funds from the rural development budget, as an important component of sustainable development (Balaban et al, 2019, p.1185). CAP become a major instrument in promoting the green development of agricultural areas in European Union (Andrei \& Darvasi, 2012; Popescu \& Andrei, 2011). According to Gajić et al, (2017, p.912), public and state institutions as well as non-profit organizations play an important role in the development of rural tourism by providing resources, whether in the form of finance or some other form, helping to promote and improve the tourist offer of the region that are less developed.

The authors Bakić \& Hrabovski-Tomić, (2010, p.118), believe that the lower limit of profitability, i.e. utilization of accommodation capacities in tourism, is $60 \%$. Having in mind the stated data, and the seasonal character of demand, we believe that selffinancing is not a sufficient source, but quality external sources of financing are necessary for financing rural tourism. However, the author Radović, (2016, p.1062), states "self-financing has been a predominant source of financing of rural tourism in the Republic of Serbia so far." The author Milenković, (2009), points out that most countries that have developed tourism also have strong stimulating and protectionist state measures in favor of the development of this activity. Thus, it can be concluded that in the process of rural tourism development, both in underdeveloped and developed countries, the support of the state plays a significant role.

Rural tourism is recognized "as one of the tourist products of special importance for the development of tourism and as a key tourist product for most tourist destinations in Serbia" (Tourism Development Strategy of the Republic of Serbia for the period from 2016 to 2025, 2016). The goals of rural tourism development in Serbia are: diversification of the rural economy, reduction of poverty and improvement of the quality of life of the population in rural areas, as well as preservation of the country's cultural wealth, environmental protection and more balanced regional development (Program for the development of sustainable rural tourism in the Republic of Serbia, 2011).

The countries in the region, which have significantly developed rural tourism in recent decades, have very active national associations of service providers. We believe that they are a significant driver of the development of this activity. The Association of 
Tourist Farms of Slovenia has existed in Slovenia since 1997. This Association is active in the promotion, sale, creation of the Slovenian rural tourism product brand, market research, as well as education of farmers engaged in rural tourism. The most important activity of the Association is cooperation with state authorities in the process of adopting regulations and planning documents related to the development of rural tourism in this country. According to Vujko et al, (2016, p. 1466), “developed rural tourism in Slovenia contributes not only to higher profit gain by households, but also to a variety of tourism offer, preserving tradition." There is Hungarian Federation of Rural and Agro tourism in Hungary. The most important goal of this Association is the realization of activities in order to enable the improvement of living conditions of the rural population through the development of rural tourism. The national associations of rural tourism service providers in Austria have the same goals - "Urlaub am Bauernhof in Österreich", and in Romania - National Association of Rural Ecological and Cultural Tourism - ANTREC". The group of authors Sin et al, (2020, p.631), conclude that ,in Romania, areas with rich environmental and cultural landscape have specialised in rural tourism". The evolution of the Romanian tourism before the EU accession is a good example that, there are positive results when the investors and the authorities follow the same way and have the same objectives (Roşu \& Voicilaş, 2019, p.1036).

The official data, listed in the Program for the Development of Sustainable Rural Tourism in Serbia, state that rural tourism is already developed in "some parts of Vojvodina, western and central Serbia" (Program for the development of sustainable rural tourism in the Republic of Serbia, 2011). There are no more specific official data on the development of rural tourism in Serbia, and this will be the subject of research in this paper.

We present the potentials and problems in the development of rural tourism in Serbia based on the results of researches conducted in the last decade.

According to the results of the research Cvijanović et al, (2016), Serbia does not have the development of rural tourism adequate to the resources at its disposal and in accordance with the fact that rural areas make up as much as $85 \%$ of its total territory. The authors Petrović et al, (2018, p.10), conclude that "in the last decades, Serbian rural tourism has not achieved a high level of development, which resulted in low competitiveness in the international travel market". According to Dedeić, (2015, p. 35), the limitations for the development of rural tourism in Serbia are the economic backwardness of rural areas, unfavorable age and educational structure of the population, poor roads and underdeveloped tourist offer. The author Matijašević-Obradović, (2016, p.33), believes that, in order for the tourist activity to represent a significant element in the total gross domestic product of Serbia, in addition to economic investments, appropriate legal regulations are necessary".

According to the research Chroneos-Krasavac et al, (2018, p. 1573), "in many countries, rural areas are undergoing significant socio-demographic and economic changes, and this trend is also present in Serbia“. A group of authors Otović et al, (2018, p.50), points 
out that "the competitive advantage of Vojvodina, in addition to agriculture, is, above all, rural tourism." The authors Bošković et al, (2011, p.40), conclude that the future development of rural tourism in Vojvodina "will depend on state support, which must be much stronger and more active than before." According to Muha, (2013, p. 129), ,rural tourism in Vojvodina should contribute to the preservation of rural environment and cultural heritage, and also economically motivate local people to stay in the countryside". A group of authors Krejić et al, (2019, p.54), point out that the key to development is that "companies in the tourist market of Vojvodina compete and that the main criterion of business is their efficiency." In the literature, we find the conclusion that agritourism is a very suitable additional source of income for agricultural farms in Vojvodina Bošković \& Maksimović, (2017, p.45). The author Petrović, (2016, p.48), believes that in order to improve the tourist offer in Srem, it is necessary to educate the bearers of rural households, analyze the tourist market, invest in infrastructure and create a safe environment, as well as strengthen cooperation with the local population.

Some researchers give suggestions on how to improve the tourist offer in rural areas. The group of authors, Jegdić et al, (2017, p. 233), suggests that "placing the organically produced products into the tourism offer would ensure profitability and sustainability of organic production and authenticity of tourism offer". According to research data Čikić et al, (2015, p. 129), the development of rural tourism in Vojvodina is the result of professional support of professionals, of which 1/5 of the total number has been engaged in this area in the past few years. A group of researchers came to the conclusion in their research that "the age and gender structure are of crucial influence for the participation of potential tourists in rural tourism" (Demirović et al, 2018, p.73). The great potential for the development of rural tourism in Vojvodina is represented by farms, and the basis of the tourist offer of farms is authentic local dishes and drinks with the taste of traditional cuisine (Vujko et al, 2017, p.60).

Other regions in Serbia also have potentials for the development of various forms of rural tourism. According to Ilić et al, (2020, p.157), „the Strategy of the Timok region in Eastern Serbia should be based on Healthy-sports and recreational tourism because the investments in this project are lower than the investment of other projects of tourism". A group of authors concludes that Serbia has a good resource potential for the development of ecotourism (Matijašević-Obradović, 2017, p.29). According to Vujko et al, $(2018$, p.81), "the development and realization of rural tourism in the municipality of Šabac must take place through cooperation not only at the level of local communities, but also through regional cooperation and integration into wider international programs". A group of authors states "we could conclude that many of the most significant tourist attractions in Šmadija are located in the rural area, and that there is potential for the development of different forms of tourism, besides rural, primarily cultural and tourism of special interest" (Matić et al, 2019, p.883). According to Milićević et al, (2020, p.235), "all this would contribute to faster development of ecotourism as well as greater competitiveness of Mount Goč in the eco-tourism market”. 
In almost all regions in Serbia, there are opportunities for the development of Wine tourism, as a special form of rural tourism. For that purpose, a group of authors proposes "creating and managing desired image and reputation represents a basis for successful positioning of a winery in the consciousness of visitors" (Jević et al, 2019, p.1167). Considering that modern tourists are increasingly demanding, better organization of entities that make up the rural tourist offer in Serbia is needed. According to Mirčetić et al, (2019, p. 862), ,organizations working in tourism sphere have to achieve an optimal level of their business process". Some regions have noted an expansion in the development of rural tourism in recent years. Such is the case in the Moravica district, in Ivanjica and its surroundings. A group of authors on the basis of the realized research concludes "the tourism potential of this area is not completely exploited" (Sagić et al, 2019, p.847). Some rural areas regularly have a better position in the tourist market. According to the research Pavlović \& Čavlin, (2014, p.610), ,taking into account the categorization of accommodation, not just the number, villages on Zlatibor show advantage“.

\section{Causes and consequences of underdevelopment rural tourism in Serbia}

Rural tourism began to develop in Serbia in the 1970s, earlier than in other republics of the Socialist Federal Republic of Yugoslavia. However, rural tourism in Serbia today is less developed than in Slovenia and Croatia, as well as other countries in the region (Radović, 2017). We believe that the causes are numerous and can be found in the previous, but also in the current period: (a) rural tourism has never been seen as a primary priority in the development of tourism in Serbia, although $85 \%$ of the territory is rural; (b) there is a lack of financial resources for the development of all aspects of the offer (catering and accommodation facilities and tourist facilities); (c) there is insufficient financial investment in the maintenance and development of rural transport and communal infrastructure; (d) there is an insufficient association and education of service providers; (e) there is insufficient promotion and development of the brand in the domestic and foreign markets; (f) there is a lack of interest of travel agencies to sell this product due to low margins; $(\mathrm{g}$ ) there is a lack of service quality standards and a lack of an institution at the national level that would deal with categorization and thus avoid the subjectivity of local governments in interpreting norms; (h) there is a lack of official data on the number of service providers and tourist traffic that they realize.

The causes of underdevelopment are also on the demand side. Due to increasing social stratification and the disappearance of the middle class, which was traditionally the buyer of this tourist product, sales have also decreased. The hosts turned more to foreign guests, but their expectations, apart from natural beauties and gastronomic pleasures, were usually not met. The expected quality of services, which includes a certain category, was mostly absent. Another problem is the lack of tourist facilities. The stated shortcomings of the offer are also most often mentioned by domestic tourists, who were unintendedly directed to rural tourism by the current epidemic caused by the corona virus. 
The consequences of the underdevelopment of rural tourism are, above all, the underdevelopment of rural economies, because agriculture alone cannot be the force of economic development. As a result, there is an increasing migration from rural to urban areas, in order to find employment and better living conditions. The rural population is getting older, and there are villages without any inhabitants. The cultural and historical heritage of rural areas is slowly disappearing. On the other hand, overcrowding and unemployment occur in urban areas.

\section{Methodology and Data Sources}

The aim of this paper is to analyze the development of rural tourism in Serbia. For that purpose, a survey was conducted in 11 administrative districts and 31 municipalities on the territory of Serbia. There are districts: West Bačka, Zlatibor, South Bačka, Kolubara, South Banat, Mačva, Šumadija, Moravica, Pirot, North Bačka and Srem. Based on the current data of the National Association "Rural Tourism of Serbia", rural tourism is represented in 85 municipalities (http://www.selo.co.rs). It can be concluded that the sample represents $36 \%$ of the total number of municipalities in whose area rural tourism is represented in Serbia in the current period. Municipalities were selected on the basis of monitoring reservations, i.e. the interest of tourists in rural tourism in their area in the previous one-year period. In order to present the results of the research, the method of synthesis was used, i.e. the data were presented at the level of the district, and not the municipality, for the purpose of better visibility.

It is necessary to point out the fact that in Serbia there are no official data on the number of entities engaged in rural tourism, as well as on the tourist traffic that they realize. These data will be available only after the introduction of the "e turista" portal, which is defined by the latest amendments to the Law on Tourism (Law on Tourism, 2019). Therefore, the research uses data from the National Association "Rural Tourism of Serbia", which has the most complete database of rural tourism entities in Serbia. This association was founded in 2002 and is the representative of the Republic of Serbia in the European Organization for Rural Tourism (EUROGITES).

The survey included 104 agricultural farms engaged in rural tourism. According to the data of the last official census of agriculture, there are a total of 514 agricultural farms in Serbia engaged in rural tourism (Census of Agriculture 2012, pp.190-197). Based on the above, it can be concluded that the sample includes $20 \%$ of the total number of agricultural farms engaged in rural tourism in Serbia. The sample was selected by random sampling.

The instrument used in the research is a questionnaire. The questionnaire included questions on the length of the period dealing with rural tourism, the number of realized tourist nights and the amount of realized income in the last year, investment planning and financing, as well as the share of marketing costs in total expenditure.

The main hypothesis is: rural tourism in Serbia is underdeveloped. The auxiliary hypothesis is: rural tourism entities that invest in marketing earn higher incomes, i.e. 
have a better development of rural tourism. The paper uses the method of field and survey research, analysis, synthesis, as well as comparative and statistical methods. In the statistical processing of data obtained by the survey, the following methods were used: descriptive statistical analysis, non-parametric statistical test - $\chi^{2}$ (Chi-square) test. Data were processed by SPPS software package.

\section{Research Results and Discussion}

The results of statistical processing of data on the length of the period of rural tourism are presented in Table 1.

Table 1 - Length of the period of dealing with rural tourism

\begin{tabular}{|c|c|c|c|c|c|c|c|c|c|c|}
\hline \multirow{3}{*}{ Districts } & \multicolumn{10}{|c|}{ Length of the period of dealing with rural tourism } \\
\hline & \multicolumn{2}{|c|}{ Up to 1 year } & \multicolumn{2}{|c|}{ 1-3 years } & \multicolumn{2}{|c|}{ 3-5 years } & \multicolumn{2}{|c|}{ More than 5} & \multicolumn{2}{|c|}{ TOTAL } \\
\hline & Number & $\%$ & Number & $\%$ & Number & $\%$ & Number & $\%$ & Number & $\%$ \\
\hline West Bačka & 6 & 55 & 2 & 18 & 2 & 18 & 1 & 9 & 11 & 100 \\
\hline Zlatibor & - & - & 3 & 12 & 10 & 40 & 12 & 48 & 25 & 100 \\
\hline $\begin{array}{l}\text { South } \\
\text { Bačka }\end{array}$ & 2 & 29 & 1 & 14 & 1 & 14 & 3 & 43 & 7 & 100 \\
\hline Kolubara & - & - & - & - & 4 & 36 & 7 & 64 & 11 & 100 \\
\hline South Banat & - & - & - & - & 1 & 14 & 6 & 86 & 7 & 100 \\
\hline Mačva & - & - & 2 & 40 & 3 & 60 & - & - & 5 & 100 \\
\hline Šumadija & - & - & 4 & 36 & 2 & 18 & 5 & 46 & 11 & 100 \\
\hline Moravica & - & - & 2 & 18 & 3 & 27 & 6 & 55 & 11 & 100 \\
\hline Pirot & - & - & 2 & 33 & 4 & 67 & - & - & 6 & 100 \\
\hline $\begin{array}{l}\text { North } \\
\text { Bačka }\end{array}$ & - & - & - & - & 2 & 40 & 3 & 60 & 5 & 100 \\
\hline Srem & - & - & 3 & 60 & 2 & 40 & - & - & 5 & 100 \\
\hline TOTAL & 8 & 8 & 19 & 18 & 34 & 33 & 43 & 41 & 104 & 100 \\
\hline
\end{tabular}

Source: Statistical processing of the survey research

It can be concluded that, observed in all districts, the largest number of surveyed entities (41\%) have been engaged in rural tourism for more than five years. The number of subjects engaged in this activity is from three to five years $(33 \%)$, from one to three years $(18 \%)$ and up to one year $(8 \%)$. Stated information points to the conclusion that the surveyed subjects have sufficient experience in dealing with rural tourism, and their answers can be considered relevant in the research. Observed by districts, the surveyed entities in the area of West Bačka are engaged in rural tourism the shortest and the longest in the area of Zlatibor district.

The results of statistical processing of data on the number of realized overnight stays in the last year are presented in Table 2. It can be concluded that in total observed in all districts, the largest number of surveyed entities (39\%) realize up to 100 tourist overnight stays per year. In terms of number, the following are entities that realize up to 300 overnight stays and they make up $32 \%$ of the total number of respondents. Entities that realize up to 500 tourist overnight stays per year make up $16 \%$ of the 
total respondents, and $13 \%$ of the surveyed rural tourism entities realize more than 500 tourist overnight stays per year. Considering that the entities that realize up to 100 tourist nights per year have the largest individual participation, and that they together with the entities that realize up to 300 tourist nights (which is also insufficient for optimal capacity utilization) make up $71 \%$ of the total number of surveyed entities, we can conclude that rural tourism in Serbia is underdeveloped. This is also a confirmation of the main hypothesis.

Table 2 - Number of realized tourist nights

\begin{tabular}{|c|c|c|c|c|c|c|c|c|c|c|}
\hline \multirow{3}{*}{ Districts } & \multicolumn{10}{|c|}{ Number of realized tourist nights } \\
\hline & \multicolumn{2}{|c|}{ Up to 100} & \multicolumn{2}{|c|}{$100-300$} & \multicolumn{2}{|c|}{$300-500$} & \multicolumn{2}{|c|}{ More than 500} & \multicolumn{2}{|c|}{ TOTAL } \\
\hline & Number & $\%$ & Number & $\%$ & Number & $\%$ & Number & $\%$ & Number & $\%$ \\
\hline West Bačka & 10 & 91 & 1 & 9 & - & - & - & - & 11 & 100 \\
\hline Zlatibor & 10 & 40 & 7 & 28 & 4 & 16 & 4 & 16 & 25 & 100 \\
\hline $\begin{array}{l}\text { South } \\
\text { Bačka }\end{array}$ & 6 & 86 & 1 & 14 & - & - & - & - & 7 & 100 \\
\hline Kolubara & - & - & 8 & 73 & 3 & 27 & - & - & 11 & 100 \\
\hline $\begin{array}{l}\text { South } \\
\text { Banat }\end{array}$ & - & - & 1 & 14 & 4 & 57 & 2 & 29 & 7 & 100 \\
\hline Mačva & - & - & 5 & 100 & - & - & - & - & 5 & 100 \\
\hline Šumadija & 5 & 45 & 1 & 9 & 3 & 28 & 2 & 18 & 11 & 100 \\
\hline Moravica & 5 & 45 & 1 & 9 & 3 & 28 & 2 & 18 & 11 & 100 \\
\hline Pirot & 3 & 50 & 3 & 50 & - & - & - & - & 6 & 100 \\
\hline $\begin{array}{l}\text { North } \\
\text { Bačka }\end{array}$ & 2 & 40 & - & - & - & - & 3 & 60 & 5 & 100 \\
\hline Srem & - & - & 5 & 100 & - & - & - & - & 5 & 100 \\
\hline TOTAL & 41 & 39 & 33 & 32 & 17 & 16 & 13 & 13 & 104 & 100 \\
\hline
\end{tabular}

Source: Statistical processing of the survey research

Observed by districts, the surveyed entities that realize up to 100 tourist overnight stays per year are mostly in the districts of West Bačka, South Bačka, Šumadija and Moravica, but these entities also make up $40 \%$ of the surveyed entities in the Zlatibor district. More than 500 tourist overnight stays are realized by the surveyed subjects in the area of North Bačka, Moravica, Šumadija, Zlatibor and South Banat districts. In this group are entities that have been engaged in rural tourism for more than 10 years, already having a strong market position.

The results of statistical processing of data on the amount of realized total income from rural tourism in the last year are presented in Table 3. Based on the presented data, it can be concluded that, observed in all districts, the largest number of surveyed entities (36\%) realize annual income up to RSD 150,000. Annual income up to RSD 300,000 is realized by $24 \%$, up to RSD 500,000 by $14 \%$, up to RSD $1,000,000$ by $9 \%$, and over RSD $1,000,000$ by $17 \%$ of the total number of surveyed entities. Therefore, in the sample surveyed, the subjects with the lowest annual income have the largest share, which points to the conclusion that rural tourism in Serbia is underdeveloped, i.e. it 
confirms the main hypothesis. In terms of the type of service provided by the surveyed entities to tourists, the results are as follows: (a) full board service is provided by $67.3 \%$; (b) overnight service only 14.4\%; (c) bed and breakfast service 13.5\%; (d) half board service $2.9 \%$; (e) catering service only $1.9 \%$. These facts point to the conclusion that the largest number of surveyed entities provides full board services to tourists, but this is not visible on the realized income due to the small number of tourist visits.

Table 3 - The amount of realized income in rural tourism

\begin{tabular}{|c|c|c|c|c|c|c|c|c|c|c|c|c|}
\hline \multirow{3}{*}{ Districts } & \multicolumn{12}{|c|}{ The amount of realized income in rural tourism } \\
\hline & \multicolumn{2}{|c|}{$\begin{array}{c}\text { up to } \\
\text { RSD } \\
\mathbf{1 5 0 , 0 0 0}\end{array}$} & \multicolumn{2}{|c|}{$\begin{array}{c}150,000- \\
300,000 \\
\text { RSD }\end{array}$} & \multicolumn{2}{|c|}{$\begin{array}{c}300,000- \\
500,000 \\
\text { RSD }\end{array}$} & \multicolumn{2}{|c|}{$\begin{array}{l}500,000- \\
1,000,000 \\
\text { RSD }\end{array}$} & \multicolumn{2}{|c|}{$\begin{array}{c}\text { more } \\
\text { than RSD } \\
1,000,000\end{array}$} & \multicolumn{2}{|c|}{ TOTAL } \\
\hline & Broj & $\%$ & Broj & $\%$ & Broj & $\%$ & Broj & $\%$ & Broj & $\%$ & Broj & $\%$ \\
\hline $\begin{array}{l}\text { West } \\
\text { Bačka }\end{array}$ & 10 & 91 & - & - & 1 & 9 & - & - & - & 9 & 11 & 100 \\
\hline Zlatibor & 8 & 32 & 5 & 20 & 3 & 12 & - & - & 9 & 36 & 25 & 100 \\
\hline $\begin{array}{l}\text { South } \\
\text { Baćka } \\
\end{array}$ & 5 & 71 & 2 & 29 & - & - & - & - & - & - & 7 & 100 \\
\hline Kolubara & - & - & 4 & 36 & 2 & 18 & 5 & 46 & - & - & 11 & 100 \\
\hline $\begin{array}{l}\text { South } \\
\text { Banat }\end{array}$ & -- & - & - & - & 2 & 29 & 3 & 43 & 2 & 28 & 7 & 100 \\
\hline Mačva & - & -- & - & - & 5 & 100 & - & - & - & - & 5 & 100 \\
\hline Šumadija & 3 & 28 & 4 & 36 & 1 & 9 & 1 & 9 & 2 & 18 & 11 & 100 \\
\hline Moravica & 6 & 55 & 3 & 27 & - & - & - & - & 2 & 18 & 11 & 100 \\
\hline Pirot & 3 & 50 & 2 & 33 & 1 & 17 & - & - & - & - & 6 & 100 \\
\hline $\begin{array}{l}\text { North } \\
\text { Bačka }\end{array}$ & - & - & 2 & 40 & - & - & - & - & 3 & 60 & 5 & 100 \\
\hline Srem & 2 & 40 & 3 & 60 & - & - & - & - & - & - & 5 & 100 \\
\hline TOTAL & 37 & 36 & 25 & 24 & 15 & 14 & 9 & 9 & 18 & 17 & 104 & 100 \\
\hline
\end{tabular}

Source: Statistical processing of the survey research

The entities that generate the highest annual revenues are located in the Zlatibor, South Banat, Šumadija, Moravica and North Bačka districts. These entities have a developed market position, but most of them also generate income from the sale of their own agricultural products and preserved food to tourists, the so-called "Takeaway". Also, according to the results of the research, it can be concluded that these entities, in addition to quality service, which includes mostly, full board, provide tourists with quality tourist facilities such as swimming pools, saunas and the like. 
Table 4 - Investment planning

\begin{tabular}{|c|c|c|c|c|c|c|}
\hline \multirow{2}{*}{ Districts } & \multicolumn{7}{|c|}{ Investment planning } \\
\cline { 2 - 7 } & \multicolumn{2}{|c|}{ Yes } & \multicolumn{2}{c|}{ No } & \multicolumn{2}{c|}{ TOTAL } \\
\cline { 2 - 7 } & Number & $\mathbf{\%}$ & Number & $\mathbf{\%}$ & Number & $\%$ \\
\hline West Bačka & 5 & 45 & 6 & 55 & $\mathbf{1 1}$ & 100 \\
\hline Zlatibor & 11 & 44 & 14 & 56 & $\mathbf{2 5}$ & 100 \\
\hline South Bačka & 3 & 43 & 4 & 57 & $\mathbf{7}$ & 100 \\
\hline Kolubara & 2 & 18 & 9 & 82 & $\mathbf{1 1}$ & 100 \\
\hline South Banat & 2 & 29 & 5 & 71 & $\mathbf{7}$ & 100 \\
\hline Mačva & 3 & 60 & 2 & 40 & $\mathbf{5}$ & 100 \\
\hline Sumadija & 5 & 45 & 6 & 55 & $\mathbf{1 1}$ & 100 \\
\hline Moravica & 10 & 91 & 1 & 9 & $\mathbf{1 1}$ & 100 \\
\hline Pirot & 3 & 50 & 3 & 50 & $\mathbf{6}$ & 100 \\
\hline North Bačka & 1 & 20 & 4 & 80 & $\mathbf{5}$ & 100 \\
\hline Srem & 4 & 80 & 1 & 20 & $\mathbf{5}$ & 100 \\
\hline TOTAL & $\mathbf{4 9}$ & 47 & $\mathbf{5 5}$ & 53 & $\mathbf{1 0 4}$ & 100 \\
\hline
\end{tabular}

Source: Statistical processing of the survey research

The results of statistical processing of the survey results, in terms of investment planning for the next five years, are presented in Table 4. Investments include the development of tourist capacity, as well as the development of tourist facilities. Based on the presented data, it can be concluded that, observed for all districts, the largest number of surveyed entities, as many as 53\%, do not plan investments. This explains that there is no investment in development, i.e. there is underdevelopment of rural tourism, which confirms the main hypothesis of this research. Entities planning investments make up the majority of the surveyed entities only in three districts: Mačva, Moravica and Srem. A five-year period was used in the survey questionnaire because that length of the investment period is most present among the surveyed rural tourism entities in Serbia.

The results of statistical processing of survey results, in terms of the share of marketing costs in the structure of total annual expenditures of surveyed rural tourism entities in Serbia are presented in Table 5. Marketing costs include costs for paid promotion in printed and electronic media, fairs, flyers etc. Based on the presented data, it can be concluded that $48 \%$ of the total number of respondents do not allocate funds for marketing costs at all. Such a business attitude will reflect on the underdevelopment of rural tourism in Serbia in the future. About $30 \%$ of the total number of surveyed entities allocates about $1 \%$ of the annual expenditure for marketing costs. For these costs, it is allocated up to $5 \%$ of annual expenditures of $10 \%$ of the total number of respondents. 
Table 5 - Share of marketing costs in the total expenditure structure

\begin{tabular}{|c|c|c|c|c|c|c|c|c|c|c|}
\hline & \multicolumn{7}{|c|}{ Share of marketing costs in the total expenditure structure } \\
\cline { 2 - 13 } & $\begin{array}{c}\text { no } \\
\text { Districts }\end{array}$ & \multicolumn{2}{|c|}{ about 1\% } & \multicolumn{1}{c|}{$\mathbf{1 \% - 5 \%}$} & \multicolumn{2}{|c|}{ more than 5\% } & \multicolumn{2}{c|}{ TOTAL } \\
\cline { 2 - 13 } & Number & $\%$ & Number & $\%$ & Number & $\%$ & Number & $\%$ & Number & $\%$ \\
\hline $\begin{array}{c}\text { West } \\
\text { Bačka }\end{array}$ & 4 & 36 & 2 & 18 & 2 & 18 & 3 & 28 & 11 & 100 \\
\hline Zlatibor & 8 & 32 & 5 & 20 & 7 & 28 & 5 & 20 & 25 & 100 \\
\hline $\begin{array}{c}\text { South } \\
\text { Bačka }\end{array}$ & 2 & 29 & 2 & 29 & - & - & 3 & 42 & 7 & 100 \\
\hline Kolubara & 9 & 82 & 2 & 18 & - & - & - & - & 11 & 100 \\
\hline $\begin{array}{c}\text { South } \\
\text { Banat }\end{array}$ & 5 & 71 & 2 & 29 & - & - & - & - & 7 & 100 \\
\hline Mačva & 3 & 60 & 2 & 40 & - & - & - & - & 5 & 100 \\
\hline Sumadija & 5 & 45 & 6 & 55 & - & - & - & - & 11 & 100 \\
\hline Moravica & 9 & 82 & 2 & 18 & - & - & - & - & 11 & 100 \\
\hline Pirot & 4 & 67 & 2 & 33 & - & - & - & - & 6 & 100 \\
\hline $\begin{array}{c}\text { North } \\
\text { Bačka }\end{array}$ & 1 & 20 & 1 & 20 & 1 & 20 & 2 & 40 & 5 & 100 \\
\hline Srem & - & - & 5 & 100 & - & - & - & - & 5 & 100 \\
\hline TOTAL & $\mathbf{5 0}$ & 48 & $\mathbf{3 1}$ & 30 & $\mathbf{1 0}$ & 10 & $\mathbf{1 3}$ & 12 & $\mathbf{1 0 4}$ & 100 \\
\hline
\end{tabular}

Source: Statistical processing of the survey research

It could be optimistic that $12 \%$ of the surveyed rural tourism entities invest more than $5 \%$ of their annual expenditure in their promotion. However, these subjects of rural tourism are located only in the area of four districts: Zlatibor, South, West and North Bačka.

Table 6 - - Investments in marketing compared to realized revenues

\begin{tabular}{|c|c|c|c|c|c|c|c|}
\hline \multirow{2}{*}{$\begin{array}{l}\text { Marketing } \\
\text { investments: }\end{array}$} & \multirow[b]{2}{*}{ Results: } & \multicolumn{5}{|c|}{ Realized annual revenues (in RSD) } & \multirow[b]{2}{*}{ Total: } \\
\hline & & $\begin{array}{c}\text { to } \\
150,000\end{array}$ & to 300,000 & to 500,000 & to $1,000,000$ & $\begin{array}{c}\text { more than } \\
1,000,000\end{array}$ & \\
\hline \multirow{3}{*}{- no } & Number & 16 & 6 & 4 & 0 & 1 & 27 \\
\hline & \begin{tabular}{|l|}
$\begin{array}{l}\text { Expected } \\
\text { number }\end{array}$ \\
\end{tabular} & 9,6 & 6,5 & 3,9 & 2,3 & 4,7 & 27,0 \\
\hline & $\%$ & $59,3 \%$ & $22,2 \%$ & $14,8 \%$ & $0,0 \%$ & $3,7 \%$ & $100,0 \%$ \\
\hline \multirow{3}{*}{- yes } & Number & 21 & 19 & 11 & 9 & 17 & 77 \\
\hline & \begin{tabular}{|l|}
$\begin{array}{l}\text { Expected } \\
\text { number }\end{array}$ \\
\end{tabular} & 27,4 & 18,5 & 11,1 & 6,7 & 13,3 & 77,0 \\
\hline & $\%$ & $27,3 \%$ & $24,7 \%$ & $14,3 \%$ & $11,7 \%$ & $22,1 \%$ & $100,0 \%$ \\
\hline \multirow{3}{*}{ Total: } & Number & 37 & 25 & 15 & 9 & 18 & 104 \\
\hline & \begin{tabular}{|l|} 
Expected \\
number
\end{tabular} & 37,0 & 25,0 & 15,0 & 9,0 & 18,0 & 104,0 \\
\hline & $\%$ & $35,6 \%$ & $24,0 \%$ & $14,4 \%$ & $8,7 \%$ & $17,3 \%$ & $100,0 \%$ \\
\hline
\end{tabular}

Source: Statistical processing of the survey research 
The auxiliary hypothesis is: rural tourism entities that invest in marketing earn higher incomes, i.e. have a better development of rural tourism. For the purpose of proving the auxiliary hypothesis, the realized annual incomes of the surveyed subjects and (no) investment in marketing were crossed. The results of the research obtained by the method of non-parametric statistical - $\chi^{2}$ (Chi-square) test are presented in table number 6 .

The value of the Chi square of the test $(\chi 2=12.858, \mathrm{df}=4, \mathrm{p}=0.012)$ is statistically significant. Based on the above, it can be concluded that there is a connection between the amount of income and investment in marketing. This confirms the auxiliary hypothesis that higher revenues are generated by rural tourism entities that invest in marketing, i.e. those entities have a developed promotion of their rural tourism product.

\section{Conclusion}

The results of the research realized in this paper confirm the main hypothesis that rural tourism in Serbia is underdeveloped. Of the total number of surveyed entities, the largest share are entities that: (a) realize up to 100 tourist nights per year; (b) realize an annual income of up to RSD 150,000; (c) do not plan investments; (d) do not invest in marketing. The auxiliary hypothesis was also confirmed in the research. Rural tourism entities that invest in marketing also generate higher incomes, i.e. have more developed. Therefore, Serbia does not have a developed rural tourism, despite the fact that its territory is dominated by rural areas, that it is an agricultural country, and having in mind that agriculture is a platform for the development of this type of tourism. The reasons for this are numerous, and they primarily relate to problems and limitations in the development of supply, but also to the lack of demand. The consequences are the economic and social decline of rural areas. We believe that the surrounding countries are a good, comparative example for Serbia, in terms of planned development of rural tourism, the importance of associations of service providers, as well as the importance of financial support to the development of this activity, especially in the pre-accession period of European integration.

In order to ensure the balanced regional development of rural tourism in Serbia, it is necessary to form a new agile association of rural tourism service providers at the national level, which should have branches in all administrative districts. In this way, the balanced development of rural tourism would be ensured, but also the balanced rural development, as a precondition for the economic and sociological survival of rural areas. Here, it is especially necessary to emphasize the importance of rural tourism for the diversification and development of rural economies. The priority task of the association should be, in addition to strengthening the network of regional branches, the cooperation with state bodies in order to define regulations, planned documents, as well as modalities of financing tailored to the needs of service providers in rural tourism. The task of this association should be active promotion and sale of rural tourism products, education of existing members, as well as attracting new ones, so that rural tourism in Serbia becomes a model of rural development. 
We believe that in order to develop rural tourism in Serbia, it is primarily necessary to adopt a strategy for the development of only this type of tourism, as well as action plans. It is necessary to define standards, establish a national categorization institution, as well as form a register of service providers. Significant investments are needed in transport and communal rural infrastructure. In order to develop rural tourism in Serbia, the financial support of the state is also important. It was significantly represented in the surrounding countries in the pre-accession period of European integration. The surveyed subjects of rural tourism in Serbia, for the most part, have so far provided the invested funds through self-financing, and only partially with the support of state subsidies. In the current period, a competition for funds from the IPARD program is underway. In order to develop rural tourism, it is necessary to provide favorable continuous sources of financing for the development of all segments of the offer.

We believe that in order to develop rural tourism, and having in mind the knowledge about the process of development of this activity in the surrounding countries, which can be our comparative examples, it is necessary to form a new association of rural tourism entities in Serbia. The association should be the initiator of the development of this activity, as was the case in Slovenia. The existing association is engaged in only one activity important for the development of rural tourism. So far, this activity has been the promotion of rural tourism through the site.

\section{Conflict of interests}

The authors declare no conflict of interest.

\section{References}

1. Andrei, J. V., \& Darvasi, D. (2012). Perspectives and challenges in financing the new Common Agricultural Policy, a new paradigm. Journal of Food, Agriculture \& Environment, 10 (1 part 2), 904-907.

2. Bakić, O, \& Hrabovski-Tomić, E. (2010). Tourism - Concepts, Effects, Functioning, Educons University, Faculty of Business Economics, Sremska Kamenica.

3. Balaban, M, Župljanin, S. \& Nešović, D. (2019). Regional sustainability of local and rural development, Economics of Agriculture, 66(4), 1173-1186. doi:10.5937/ ekoPolj1904173B.

4. Bartlet, T. (2006). Rural Tourism development in Europa, International Forum on Rural Tourism, China, 4-6 September 2006, Final Report World Tourism Organization.

5. Bošković, N. (2003). Dynamic Changes in World Rural Tourism Development, Proceedings, Second Forum: Rural Tourism and the Sustainable Development of the Balkans, Kragujevac, 7-9. May 2003, 63-68.

6. Census of Agriculture 2012 - Agriculture in the Republic of Serbia (2012). Volume II, National Institute for Statistics, Belgrade. 
7. Bošković, T, Andrić N. \& Tomić, D. (2011). Human and financial resources - factors in the development of rural tourism in AP Vojvodina, Business school, (No.2), 3241.

8. Bošković, T. \& Maksimović, B. (2017). Development of agritourism in rural regions of the Autonomous Province of Vojvodina: Possibilities and Advantages, Agroekonomika 46(76), 35-46.

9. Chroneos-Krasavac, B, Radosavljević, K. \& Bradić-Martinović, A. (2018). SWOT analysis of the rural tourism as a channel of marketing for agricultural products in Serbia, Economics of Agriculture, 65(4), 1573-1584. DOI: https://doi.org/10.5937/ ekoPolj1804573K.

10. Cvijanović, D, Radović, G. \& Cvijanović, G. (2016). Resources and the rural tourism development in the Republic of Serbia, Horizons International Scientific Journal, $X(20), 41-51$.

11. Čikić, J, Petrović, M. \& Đurđev, B. (2015). Diffusion of knowledge and rural tourism development -example of Vojvodina, Economics of Agriculture, 62(1), 123-136. DOI: .https://doi.org/10.5937/ekoPolj1501123C.

12. Dedeić, D. (2015). The role of tourism in poverty reduction in Serbia, TIMS Acta (No. 9), 25-36.

13. .Demirović, D, Njegovan, N. \& Glavaš-Trbić. D. (2018). Motivation factors in rural tourism, Agroekonomika, 47(80), 65-74.

14. Durkalić, D., Furtula, S., \& Borisavljević, K. (2019). Ranking tourism market performance in EMU countries: Results of PROMETHEE-GAIA approach. Hotel and Tourism Management, 7(2), 67-76, doi: 10.5937/menhottur1902067D

15. Gajić, T, Vujko, A, Penić, M, Petrović, M, D. \& Mrkša, M. (2017). Significant involvement of agricultural holdings in rural tourism development in Serbia, Economics of Agriculture, 64(3), 901-918. DOI: .https://doi.org/10.5937/ ekoPolj1703901G.

16. Ilić, B, Đukić, G. \& Balaban, M. (2020). Sustainable development directions of rural tourism of Timok region, Economics of Agriculture, 67(1), 157-174. doi:10.5937/ ekoPolj2001157I.

17. Jegdić, V, Škrbić, I. \& Milošević, S. (2017). Models of entreprenurship development in rural tourism destinations in Vojvodina, Economics of Agriculture, 64(1), 227 237. DOI: .https://doi.org/10.5937/ekoPolj1701221J.

18. Jević, J, Čerović, S, Jević, G. \& Čavlin, M. (2019). Accessible tourism as the factor in creating the image of Serbian wineries as as segment of agritourism supply, Economics of Agriculture, 66(4), 1157-1171. DOI: .https://doi.org/10.5937/ ekoPolj1904157J.

19. Krejić, Ž, Milićević, S. \& Anđelković, M. (2019). The opportunities of development of rural tourism in Vojvodina, Agroekonomika, 48(84), 47-54. 
20. Lakićević, M., Žarevac, M. (2014). Tourism thought as a factor of tourism development in Serbia, Hotel and Tourism Management, 2(1), 29-37.

21. Law on Tourism, Official Gazette of the Repof Serbia no. 17/2019.

22. Matić, N, Đorđević, S. \& Vujić, M. (2019). Contemporary basis of rural tourism development in Šumadija district, Economics of Agriculture, 66(3), 869-888. DOI:https://doi.org/10.5937/ekoPolj1903869M.

23. Matijašević-Obradović, J. (2016). Legal and strategic framework for promotion of tourism and agritourism in Serbia, Agroekonomika 45(69), 35-46.

24. Matijašević-Obradović, J. (2017). The importance of environmental protection for development of ecotourism in Serbia, Agroekonomika 46(75), 21-30.

25. Milićević, S, Đorđević, N. \& Krejić, Ž. (2020). Research on tourists' attitudes on the potential of Goč mountain for the development of eco-tourism, Economics of Agriculture, 67(1), 223-238. DOI: .https://doi.org/10.5937/ekoPolj2001223M.

26. Milenković, S. (2009). Turizam i ekonomija, Univerzitet u Kragujevcu, Ekonomski fakultet.

27. Mirčetić, V, Vukotić, S. \& Cvijanović, D. (2019). The concept of business clusters and its impaction tourism business improvement, Economics of Agriculture, 66(3), 851-868. DOI:https://doi.org/10.5937/ekoPolj1903851M.

28. Muhi, B. (2013). Rural tourism as a part of integral and sustainable development of villages in Vojvodina, Zbornik Matice srpske za društvene nauke, No. (142), 129-137.

29. Otović, S, Demirović, D, Košić, K. \& Miličić, Ž. (2018). Entrepreneurship and rural tourim, Agroekonomika 47(78), 41-52.

30. Pavlović, S. \& Čavlin, G. (2014). Competitiveness of destinations within the rural tourism cluster: Zlatar, Zlatibor, Economics of Agriculture, 61(3), 603-614.

31. Pejanović, R. (2018). Contemporary problems of agriculture and the countryside in the Republic of Serbia, Agroekonomika 47(81), 15-25.

32. Petrović, N. (2016). Evaluation of tourist offer by rural households in Srem region, Agroekonomika 45(72), 41-49.

33. Petrović, M, D, Vujko, A, Gajić, T, Vuković, D, B, Radovanović, M, Jovanović, J, M. \& Vuković, N. (2018). Tourism as an Approach to Sustainable Rural Development in Post-Socialist Countries: A Comparative Study of Serbia and Slovenia, Sustainability 10 (1), 1-14. https://doi.org/10.3390/su10010054.

34. Popescu, G., \& Andrei, J. (2011). From industrial holdings to subsistence farms in Romanian agriculture. Analyzing the subsistence components of CAP. Agricultural Economics, 57(11), 555-564.

35. Program for the development of sustainable rural tourism in the Republic of Serbia, Official Gazette of the Republic of Serbia No. 85/2011. 
36. Radović, G. (2016). Sources of finance for rural tourism in the Republic of Serbia, Economics of Agriculture, 63(3), 1053-1065. DOI: https://doi.org/10.5937/ ekoPolj1603053R.

37. Radović, G. (2017). Experience of foreign countries in rural tourism development lessons for Serbia, In: Thematic Proceedings II: Tourism in function of development of the Republic of Serbia, 2nd International Scientific Conference, 1-3 June, 2017, Vrnjačka Banja, Serbia, University of Kragujevac, Faculty of hotel management and tourism in Vrnjačka Banja, 429-443.

38. Roberts, L, Mitchell, M \& Hall, D. (2005). New Directions in Rural Tourism: Local Impacts and Global Trends, in New Directions in Rural Tourism, Hall D, Roberts L. \& Mitchell M. (eds), Ashgate Publishing Limited, Aldershot, England, 225-233.

39. Roşu, E. \& Voicilaş, D-M. (2019). The Competitiveness of Tourism in Romania after EU Accession - Regional Analysis, Economics of Agriculture, 66 (4), 1023 1038. DOI:https://doi.org/10.5937/ekoPolj1904023R.

40. Rural Tourism of Serbia, Retrieved from http://www.selo.co.rs (April, 15 2020)

41. Sagić, Z, Lakićević, M. \& Durkalić, D. (2019). Analysis of tourist turnover in a rural tourism destination - case study of Ivanjica, Economics of Agriculture, 66(3), 835-850. DOI: https://doi.org/10.5937/ekoPolj1903835S.

42. Sin, A, Nowak, Cz, Bogusz, M, Kowalska, M. \& Janigová, E. (2020). Innovations in rural tourism in Poland and Romania, Economics of Agriculture, 67(2), 623-633. DOI: https://doi.org/10.5937/ekoPolj2002623S.

43. Tourism Development Strategy of the Republic of Serbia for the period from 2016 to 2025, Official Gazette of RS No. 98/2016.

44. Vujko, A, Petrović, M, D, Dragosavac, M. \& Gajić, T. (2016). Differences and similarities among rural tourism in Slovenia and Serbia - perceptions of the local tourism workers, Economics of Agriculture, 63(4), 1459-1469. DOI: 10.5937/ ekoPolj1604459V.

45. Vujko, A, Petrović, M, D, Demirović, D. \& Racković, I. (2017). Evaluation of tourism development on traditional farms (salaši) of the Bačka region, Agroekonomika 46(75), 53-61.

46. Vujko, A, Demirović, D, Petrović, M, D. \& Dupljanin, D. (2018). Tourism as a development factor of rural area in Šabac municipality, Agroekonomika 47(80), 75-83. 